\title{
Simulation and Optimisation of a Full Electric Hybrid Vehicle
}

\author{
Dr. Margit Noll,* Harald Giuliani, ${ }^{*}$ Dragan Simic, ${ }^{*}$ Valerio Conte, ${ }^{*}$ Hannes Lacher,*and \\ Peter Gollob*
}

\begin{abstract}
One of the main driving forces in automotive $R \& D$ is the reduction of fuel consumption and emissions to meet nowadays ecological, social and legal requirements. Pure battery electric or fuel cell drive trains are highly favourable in that context; however, they still suffer from severe drawbacks regarding performance, range and durability. Therefore new concepts have to be investigated taking advantage of the existing technologies and their potential. The vehicle concept considered in this paper focuses on the development of a full electric hybrid vehicle comprising of conventional electric propulsion combined with a fuel cell as range extender. The advantage of such a system is that the fuel cell is used under rather constant load conditions, which is advantageous for its durability and efficiency.

The electric hybrid vehicle concept is based on a conventional electric Citroen Berlingo (Citroen Berlingo electrique) integrating a Solid Oxid Fuel Cell (SOFC) fuelled with bio-diesel. For determination of the requirements of the fuel cell and the energy management comprehensive simulations based on a longitudinal vehicle model have been performed. The simulation results of the electric drive train have been validated on components and system level. Based on this validated vehicle model the electric hybrid vehicle concept is developed. A fuel cell model is integrated and parameter variation is performed regarding the size of the fuel cell as well as the battery. Focusing on the vehicle range, driving and charging times different concepts are investigated. The paper gives a detailed description of the vehicle simulation, the parameter variation results, the validation process and the determined optimised vehicle concepts.
\end{abstract} extender.

Keywords: electric hybrid vehicle, longitudinal vehicle simulation, electric drive train, fuel cell, range

\section{INTRODUCTION}

One of the main driving forces in automotive R\&D is the reduction of fuel consumption and emissions to meet nowadays ecological, social and legal requirements. Due to the existing legislation and regulation of emissions, the quite more restrictive regulation that may come and the apparent fuel price situation, the demand for innovative vehicle concepts increases. Pure electric propulsion is in that context one of the most promising drive technologies. However, it still suffers of shortcomings such as insufficient range and performance compared with conventional vehicles. Limiting factor in this respect is the energy storage system. Therefore many investigations are performed in that context regarding improved and new energy storage systems [1-3] as well as the development of alternative drive concepts like fuel cell vehicles $[4,5]$. Considering the current research status it has to be admitted that market introduction of fuel cell vehicles is still far to come and upcoming energy storage systems still do not meet the requirements sufficiently for a short term implementation of pure electric propulsion. Therefore, focusing on a short term introduction of

Arsenal Research

Giefinggasse 2, A-1210 Vienna, Austria

Tel: +43(0)50550-6222

(C) 2008 WEV Journal, pp. $x-x$ electric vehicles new concepts have to be investigated taking advantage of existing technologies and their potentials.

One promising concept is the combination of a battery electric power train and a fuel cell to a hybrid electric vehicle. The concept under discussion is based on a Citroen Berlingo electrique equipped with new batteries and a Solid Oxide Fuel Cell (SOFC) which will be operated with bio diesel. The combination of a battery electric power train with a fuel cell as range extender shows several advantages compared with pure battery electric vehicles or fuel cell power trains. The fuel cell range extender allows significant higher ranges at lower weight compared to pure battery driven vehicles. In addition the fuel cell is operated under rather constant load conditions, which is advantageous for its durability and efficiency.

Main objective of this study is the optimisation of such a hybrid electric power train as a basis for realisation and evaluation of a corresponding vehicle. For that purpose a vehicle model of the commercial Citroen Berlingo electrique is developed and validated. Based on that electric vehicle model the new concept is developed, appropriate batteries selected and the battery and SOFC size optimised focusing on an urban 
application.

\section{SIMULATION OF THE ELECTRIC VEHICLE}

The simulation environment applied for the study is Dymola (Dynamic Modeling Laboratory), an environment for modeling and simulation of integrated and complex systems using the simulation language Modelica [6]. The main advantage of Dymola/Modelica is the high flexibility for developing dynamic behaviour and complex interactions between (sub)systems. The models are implemented as object oriented, physical models thru algebraic and differential equations using geometrical data for parameterization. Arsenal research has developed a comprehensive Modelica-based simulation environment focusing especially on alternative vehicle concepts, such as hybrid or electric vehicles, and electric vehicle components, such as electric operated water pumps, electric air conditioning systems, etc. Core of this simulation environment is the SmartElectricDrives (SED) library [7, 8], containing electric machines, power sources, measurement devices, modern electric drive control algorithms, power electronics and battery models. The entire electric part of the Citroen Berlingo electrique vehicle model, the electric machine including their controllers, power electronic converters, power auxiliaries, as well as the battery, is based on the SED library. The mechanical components are taken from a specialized mechanics library designed for longitudinal simulations of mechanical power trains in vehicular applications - the PowerTrain library [9].

\subsection{Vehicle Model}

As a basis for the hybrid electric vehicle concept a longitudinal vehicle model of the Citroen Berlingo electrique has been developed (Figure 1). A model of an electrical excited direct current machine (eMachine) is coupled through the transmission (transmission), which is based on the automatic gearbox, to the front axle (driveAxle). The DC/DC converters of the armature and the excitation circuit are already included in the

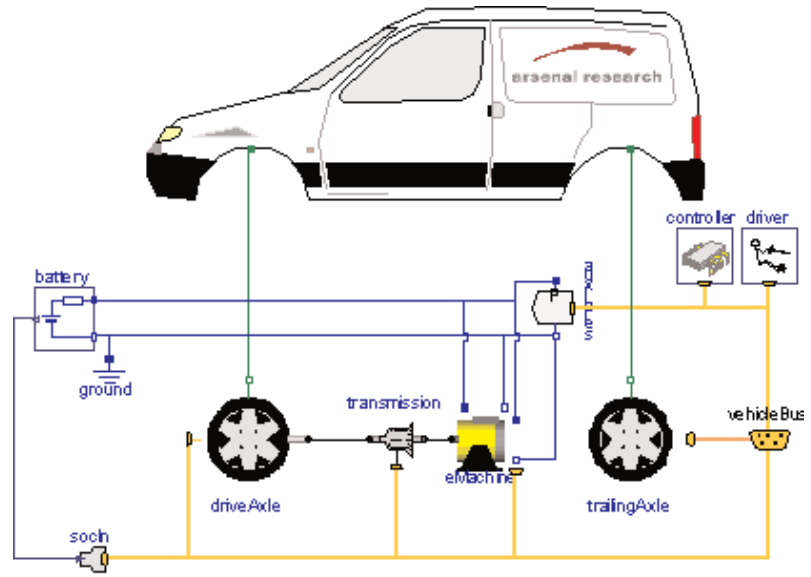

Figure 1: Vehicle model of the Citroen Berlingo electrique machine model. The chassis is connected to the axles by mechanical connectors and comprise the resistance forces of acceleration, the slope of the road, as well as the wind and rolling resistance. For efficient handling of the electrical and control signals of the different components a bus system (vehicle bus) is implemented. The sum of the power auxiliaries e.g. the car radio, the steering booster pump or the braking light are represented by a controlled power loss component (auxiliaries). The drive cycle and the driving strategy are defined by the controller and the driver block, respectively. To simplify the vehicle simulation only the energy storage for the traction drive (battery) is modelled. However, the DC/DC converter for the board system battery ( $12 \mathrm{~V}$ battery) is implemented in the power losses block (auxiliaries) and the efficiency of this converter is taken into account.

\subsection{Parameterization}

The parameterization depends on the abstraction level of the simulation model and the model accuracy. All used components need a set of parameters which have to be determined from measurements or from data sheets. For this purpose mechanical and electrical measurements were performed. Table 1 summarizes the main vehicle parameters. The battery and motor currents and voltages for different operation points have been determined from motor data (table 2) and DCDC converter losses tables.

Furthermore a two dimensional efficiency table for the armature circuit power converter is used to complete

\begin{tabular}{|c|c|c|c|}
\hline Weight & $\begin{array}{l}\text { mass of middle } \\
\text { charged car }\end{array}$ & $1625 \mathrm{~kg}$ & Mass \\
\hline \multirow{3}{*}{ Dimensions } & front area & $2.653 \mathrm{~m}^{2}$ & Area \\
\hline & wheel radius & $0.285 \mathrm{~m}$ & $\bar{R}$ \\
\hline & motor inertia & $0.2 \mathrm{kgm}^{2}$ & $\mathrm{Jr}$ \\
\hline Transmission & Sum of gear ratio & 7.35 & \\
\hline \multirow{2}{*}{$\begin{array}{l}\text { Coefficients } \\
\text { (free- } \\
\text { wheeling } \\
\text { curve) }\end{array}$} & $\begin{array}{c}\text { Coefficient of } \\
\text { aerodynamic re- } \\
\text { sistance } \\
\end{array}$ & 0.40698 & $\mathrm{cw}$ \\
\hline & $\begin{array}{c}\text { Coefficient of } \\
\text { rolling resistance }\end{array}$ & 0.0144 & fr \\
\hline
\end{tabular}

Table 1: Main vehicle parameters

\begin{tabular}{|l|r|l|}
\hline Va [V] & 162 & Nominal armature voltage \\
\hline Ia $[\mathrm{A}]$ & 110 & Nominal armature current \\
\hline Ie $[\mathrm{A}]$ & 12.5 & Nominal excitation current \\
\hline $\mathrm{n}[\mathrm{rev} / \mathrm{min}]$ & 1340 & Nominal rotor speed \\
\hline $\begin{array}{l}\text { nMax } \\
{[\mathrm{rev} / \mathrm{min}]}\end{array}$ & 6500 & Maximal rotor speed \\
\hline $\mathrm{Ra}[\mathrm{\Omega}]$ & 0.069 & Warm armature resistance \\
\hline $\mathrm{La}[\mathrm{H}]$ & 0.00169 & Armature circuit inductance \\
\hline $\operatorname{Re}[\Omega]$ & 9.47 & Warm excitation resistance \\
\hline $\mathrm{Le}[\mathrm{H}]$ & 0.0947 & Excitation circuit inductance \\
\hline
\end{tabular}

Table 2: Parameters of the electrical excited DCDC machine 
The World Electric Vehicle Journal, Vol 2, September 2008

the parameterization of the electric machine (Figure 2). The power losses of the excitation circuit DCDC converter have been neglected whereas the DCDC converter of the auxiliary battery was considered and mapped as a one dimensional efficiency table (Figure 3).

Regarding the energy storage device, two battery models with different level of complexity have been used depending on the purpose of the simulation. For the electric vehicle model a dynamic battery model has been

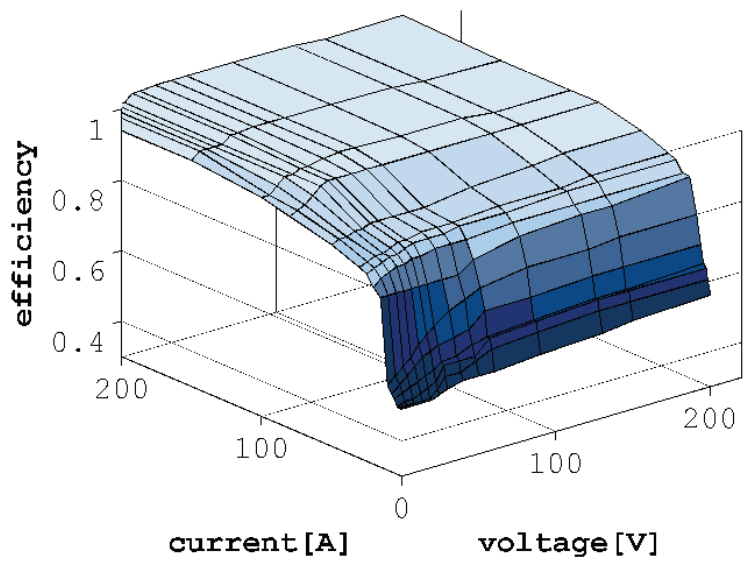

Figure 2: Efficiency of the DCDC armature circuit power converter

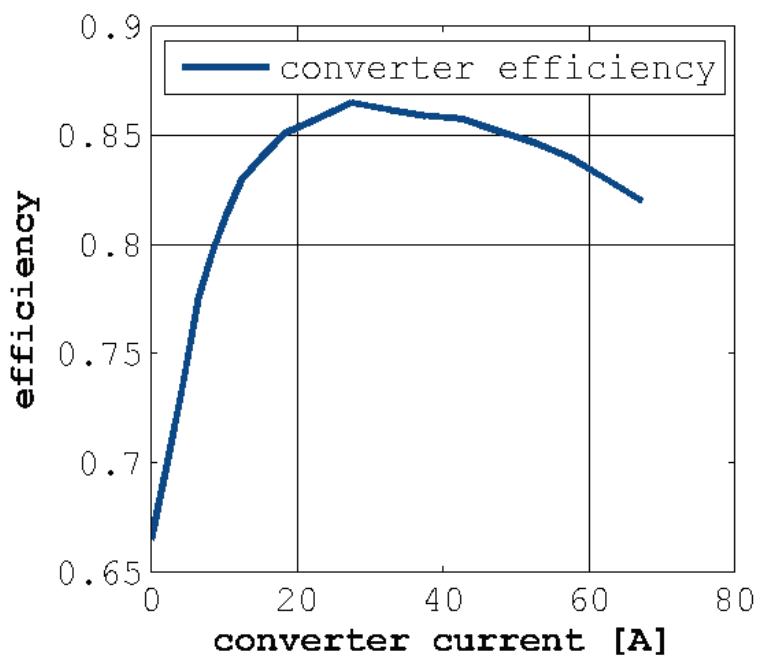

Figure 3: Efficiency of the DCDC on board (12V) circuit power converter

developed, whereas for optimisation of the hybrid electric vehicle concept a more simplified model - a linearized SED battery model - was adopted. The parameterization of the dynamic battery model is based on vehicle measurements as well as standardized charge-discharge tests. Using this model it was possible to estimate the SOC of the battery.

To consider the entire power losses of the auxiliaries the power consumption of each auxiliary has been measured (table 3 ). The auxiliary model is set up in such a way that each auxiliary can be activated and parameterized separately by the user (figure 4).

As a basic driving cycle for optimisation of the hybrid electric vehicle concept a real urban drive cycle has been used. The drive cycle is defined as velocity and slope in dependence of the position and was recorded in the city

\begin{tabular}{|l|l|}
\hline base power & $107.5 \mathrm{~W}$ \\
\hline measurement devices & $80 \mathrm{~W}$ \\
\hline main beam & $203 \mathrm{~W}$ \\
\hline dipped beam & $185 \mathrm{~W}$ \\
\hline reflector heater & $49 \mathrm{~W}$ \\
\hline auxiliary heating & $55 \mathrm{~W}$ \\
\hline radio & $14 \mathrm{~W}$ \\
\hline steering booster pump & $138.6 \mathrm{~W}$ \\
\hline wind screen wiper & Level 1: 13 W \\
\hline & Level 2: 32 W \\
\hline & Level 3: $57 \mathrm{~W}$ \\
\hline ventilator & Level 1: 36 W \\
\hline & Level 2: 74 W \\
\hline & Level 3: 130 W \\
\hline & Level 4: $234 \mathrm{~W}$ \\
\hline breaking light & \\
(in case mechanical brakes are used) & $50.4 \mathrm{~W}$ \\
\hline
\end{tabular}

Table 3: Measured power consumption of all vehicle auxiliaries

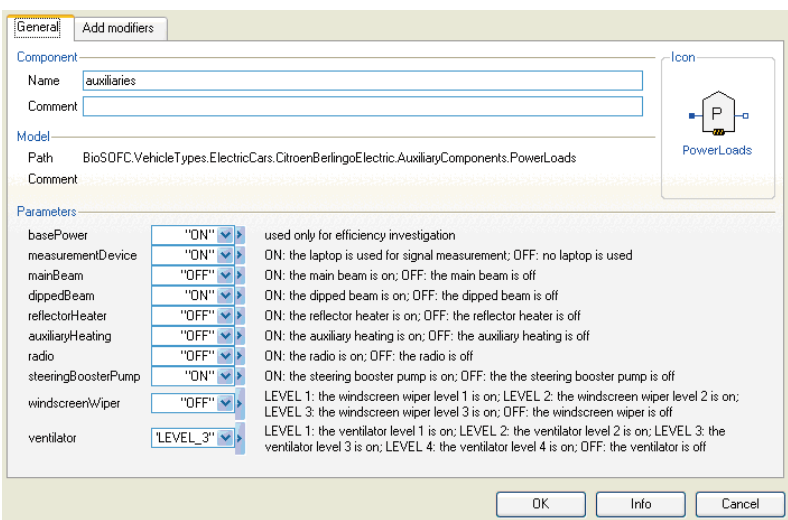

Figure 4: Parameterization of the power auxiliaries

of Vienna using GPS (Global Positioning System). The velocity distribution over the entire drive cycle is given in table 4, whereas figure 5 shows a detail of the driving cycle for illustration.

For parameterization of the driving strategy (driver) measured vehicle signals (e.g. vehicle velocity, gas and braking pedal position, armature and excitation current) have been used. Based on these measurement data a finite state machine was developed which defines the transitions between the different states. In addition these transition parameters can be easily changed in the driver block by the user.

\subsection{Model Validation}

Validation of the models was performed on components 
The World Electric Vehicle Journal, Vol 2, September 2008

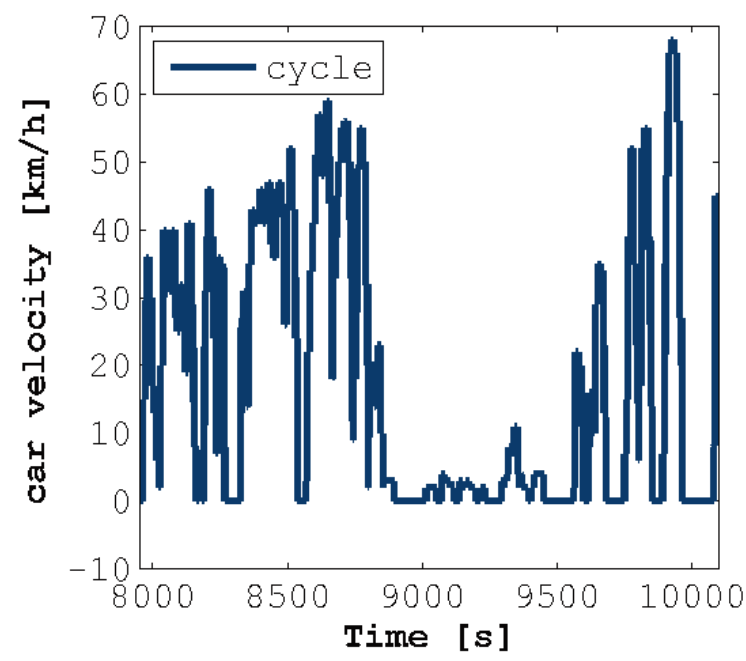

Figure 5: Detail of the drive cycle

\begin{tabular}{|c|c|}
\hline Vehicle velocity $\mathrm{v}[\mathrm{km} / \mathrm{h}]$ & $\%$ \\
\hline $\mathrm{v}==0$ & 54.75 \\
\hline $0<\mathrm{v}<10$ & 13.35 \\
\hline $10<\mathrm{v}<20$ & 6.04 \\
\hline $20<\mathrm{v}<30$ & 6.58 \\
\hline $30<\mathrm{v}<40$ & 7.13 \\
\hline $40<\mathrm{v}<50$ & 8.11 \\
\hline $50<\mathrm{v}<60$ & 3 \\
\hline $60<\mathrm{v}<70$ & 1 \\
\hline $\mathrm{v}>70$ & 0 \\
\hline
\end{tabular}

Table 4: Distribution of vehicle velocities [\%] over the entire drive cycle

and vehicle level - the mechanical geometrical parameters, the electric machine, the battery and the entire power consumption of the vehicle were analyzed.

The aerodynamic resistance coefficient and the rolling resistance coefficient have been calculated from the measured freewheeling curve. For validation of these coefficients the measured freewheeling curve is compared with the simulated one (figure 6). Simulation results are highly in accordance with the measurements, only at quasi zero velocity a slightly deviation occurs.

For validation of the electric power train the excited DCDC machine model and the battery model have been validated. The simulation was performed using a torque controlled machine. The motor is driven externally by a reference speed and the simulation covers the entire admissible motor speed range. Figure 7 gives the maximal feasible inner torque and the mechanical output power in dependence on the rotor speed. The simulation results are in good accordance with the motor manufacturer's data sheet [10] .

Based on the voltage, current, and temperature measurements performed during road tests the complex battery model was parameterized. Figure 8 gives an

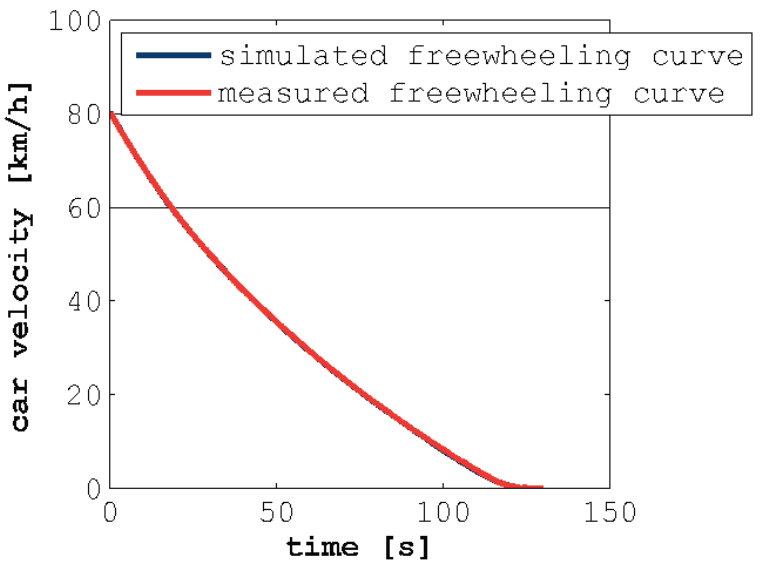

Figure 6: Mean value of measured freewheeling curve and simulated freewheeling curve

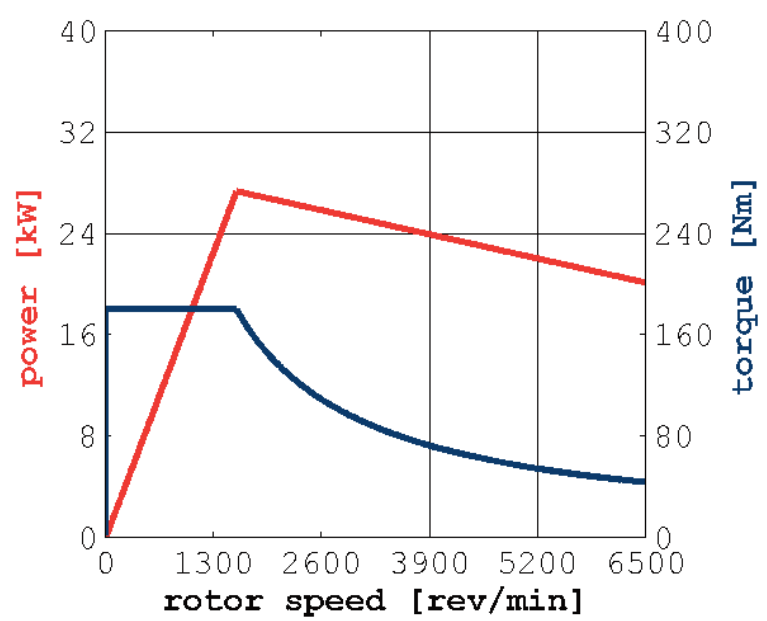

Figure 7: Characteristic curves of the electric machine example of the current recorded during a drive cycle in the city of Vienna. The measured currents were used as reference signals for the model validation. The comparison of the measured and calculated battery voltage is given in figure 9 . The deviation in the voltage is assigned to the fact that the test vehicle including the batteries is a used one and some cells were lightly damaged. The cells showed a mainly non linear and not predictable behaviour, probably due to faults in the cells' electrode plates. Therefore the battery modelling and the battery parameterisation were highly challenging. Nevertheless the overall voltage error of less then 5\% was kept in an acceptable bandwidth.

For the entire vehicle validation, simulations with different constant velocities on a slopeless route were performed and the overall delivered battery power as well as the car velocity was measured. According to the power auxiliaries switched on during the measurements, the vehicle model was parameterized and the simulation performed. Figure 10 shows the good accordance of the calculated and measured entire battery power consumption. Based on this validated 


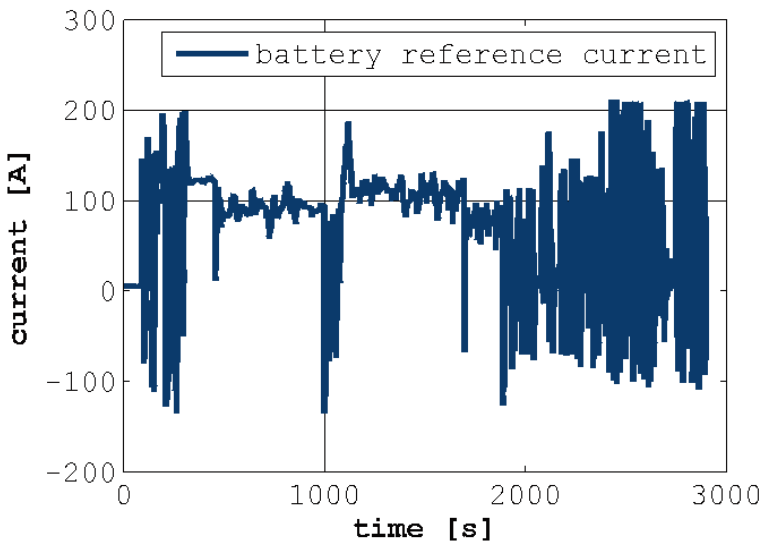

Figure 8: Reference battery current

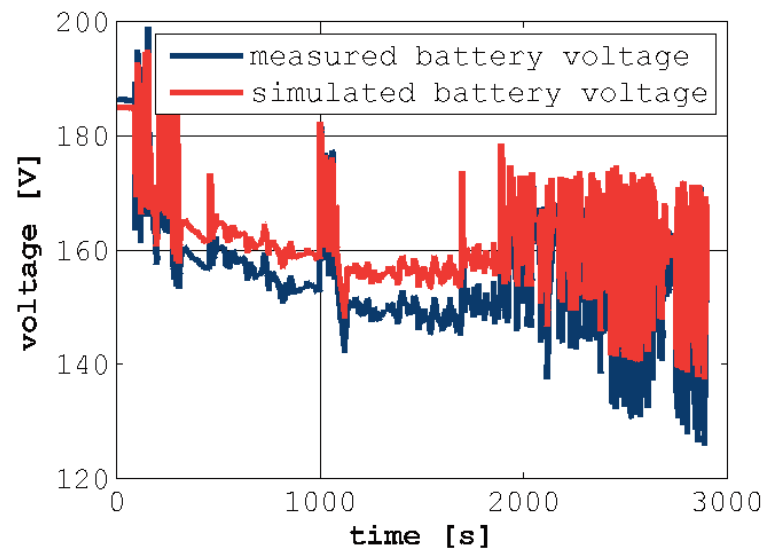

Figure 9: Measured and simulated battery voltage vehicle model the new concept has been developed.

\section{ELECTRIC HYBRID VEHICLE CONCEPT}

For realization of a range- and performance-optimized electric hybrid vehicle the investigations included the selection of appropriate batteries as well as the optimization of the battery and fuel cell size according

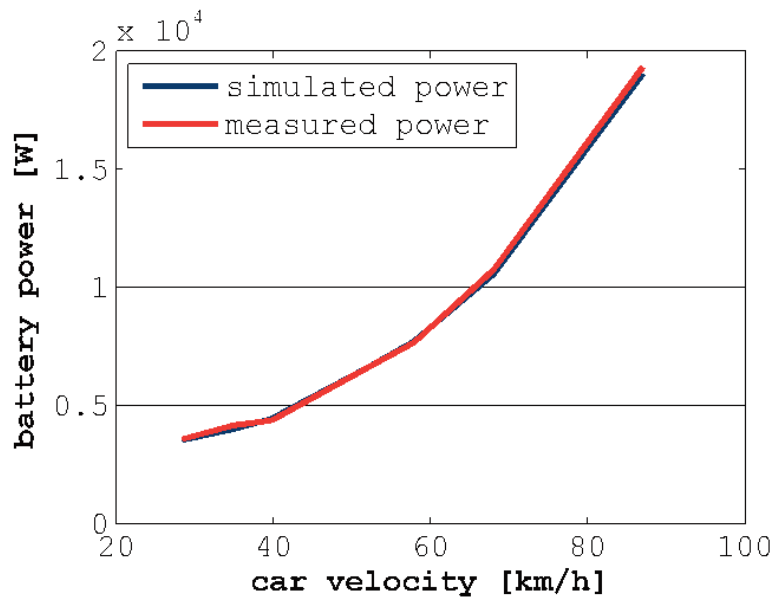

Figure 10: Measured and simulated battery power consumption for different constant car velocities

(C) 2008 WEV Journal, pp. $\mathrm{x}-\mathrm{x}$ to the given application and driving cycle, respectively. Therefore different batteries have been evaluated for their applicability for the urban driving cycle. The validated vehicle model was then enhanced by the new battery model as well as a simplified SOFC model. For range optimization of the entire system, parameter variation of the battery and the SOFC size has been performed.

\subsection{Selection of Batteries}

The variety of high potential batteries for automotive application has significantly increased in the last years. Therefore three different commercial batteries were evaluated regarding their potential for the given application - a NiMH High Power (NiMH), a Lithium Nickel Oxide (LiNiO2) and a Lithium Cobalt Oxide (LiCoO2) battery. These commercial batteries were tested at the arsenal research battery test bed. The determined parameters have been used to parameterize a simplified battery model from the SED library for comparison of the different battery technologies. Basic assumption for the comparison was in each case a battery with $100 \mathrm{Ah}$ according to the original $\mathrm{NiCd}$ battery of the Citroen Berlingo electrique. Vehicle simulations using the electric vehicle model and the different battery models were performed and the corresponding ranges determined. For calculation of the ranges the simulations were executed until the respective battery State of Charge fell below a predefined value. Using the $\mathrm{LiCoO} 2$ battery the highest range was obtained, although the $\mathrm{LiNiO} 2$ and the LiCoO2 show quite similar results (figure 11). The higher range of the $\mathrm{LiCoO} 2$ is mainly based on the significant lower weight of the battery. Therefore the $\mathrm{LiCoO} 2$ battery was chosen for the further investigations.

\subsection{Hybrid Electric Vehicle Model}

The hybrid electric vehicle model was developed by integrating the model of the selected battery and a

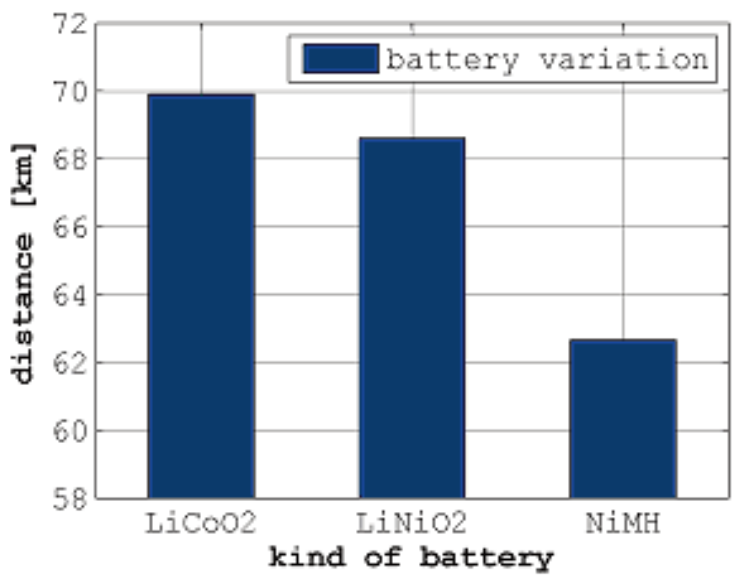

Figure 11: Comparison of different battery types with respect to the range 


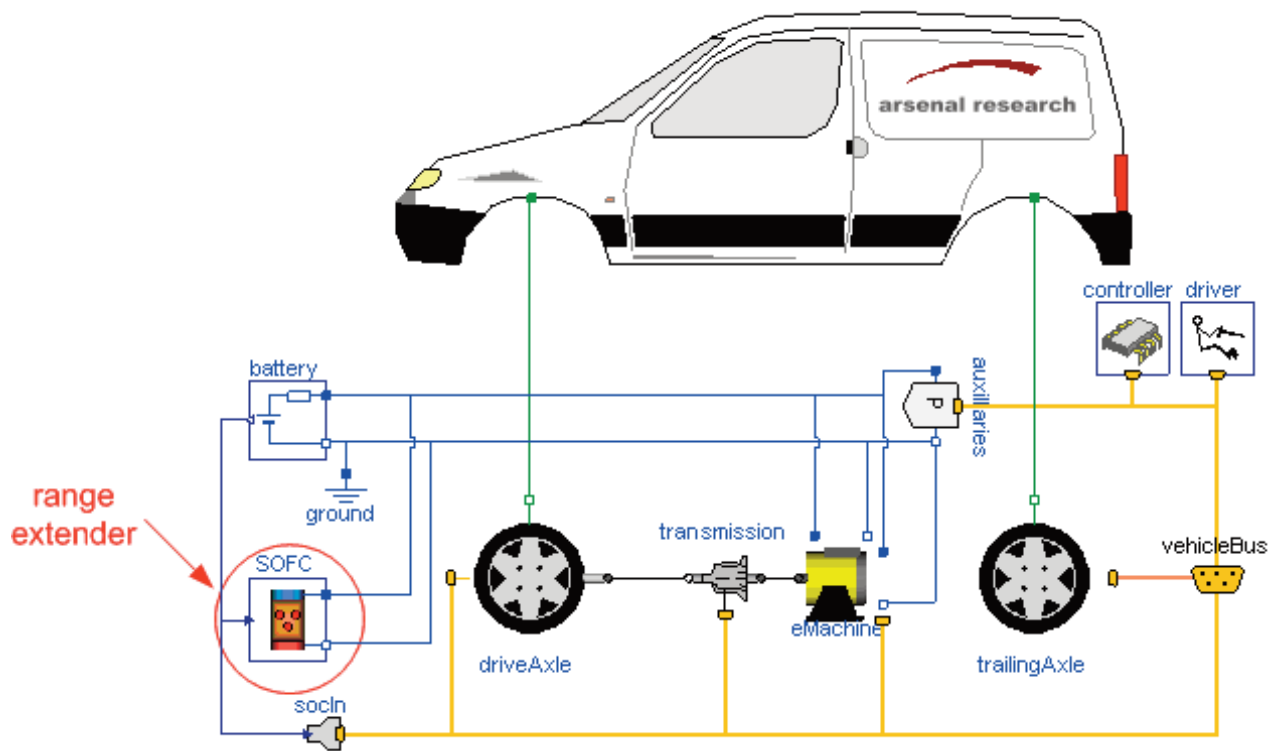

Figure 12: Simulation model of the hybrid electric vehicle

SOFC model as range extender (figure 12). The fuel cell is used under rather constant load conditions, charging the battery continuously also during vehicle standstill periods. Only in case that the battery state of charge exceeds a maximum value, the management of the range extender reduces the load current. Focusing on the optimisation of the SOFC and battery size a simplified SOFC model is considered as appropriate. Therefore the output power, the efficiency (fuel to output current), the mass and the caloric value of the fuel are used as main parameters.

\subsection{Optimization of the Electric Hybrid Vehicle Concept}

This hybrid electric vehicle model was applied for optimisation of this vehicle concept by variation of the battery and SOFC size. Parameter variation was performed using batteries with 20,40,60, and $100 \mathrm{Ah}$ as well as SOFCs with $1 \mathrm{~kW}, 2 \mathrm{~kW}$ and $3 \mathrm{~kW}$. As relevant parameters for the optimisation process the driving range and time as well as the charging time and the fuel consumption are determined for the different batterySOFC combinations using the real urban driving cycle (figure 4, table 4). In addition for the $100 \mathrm{Ah}$ battery also the electric vehicle without range extender was considered for benchmark. The results are given in figure 13 to 16 .

Regarding driving range and time it can be seen that a range extender of $1 \mathrm{~kW}$ allows no significant improvement compared to the pure battery electric power train and that the $20 \mathrm{Ah}$ battery would require a much larger SOFC to allow an appropriate range. On the other hand the $2 \mathrm{~kW}$ and $3 \mathrm{~kW}$ range extender in combination with the $100 \mathrm{Ah}$ battery allows a duplication and triplication of the range, respectively. Also the $40 \mathrm{Ah}$ and $60 \mathrm{Ah}$ battery combined with the 3
$\mathrm{kW}$ range extender gives ranges of at least $150 \mathrm{~km}$. Focusing on the other hand on the charging time any battery-SOFC combination - except the $1 \mathrm{~kW}$ SOFC which has already been excluded - requires less than 7 hours charging time. Based on the determined range and the given urban driving cycle several combinations seem appropriate to allow at least a duplication of the range (table 5). 
The World Electric Vehicle Journal, Vol 2, September 2008

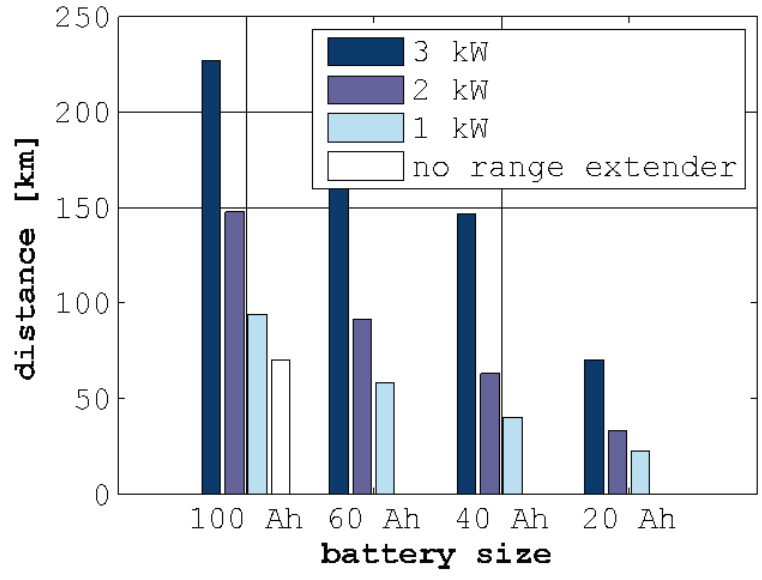

Figure 13: Parameter variation: drive-distance

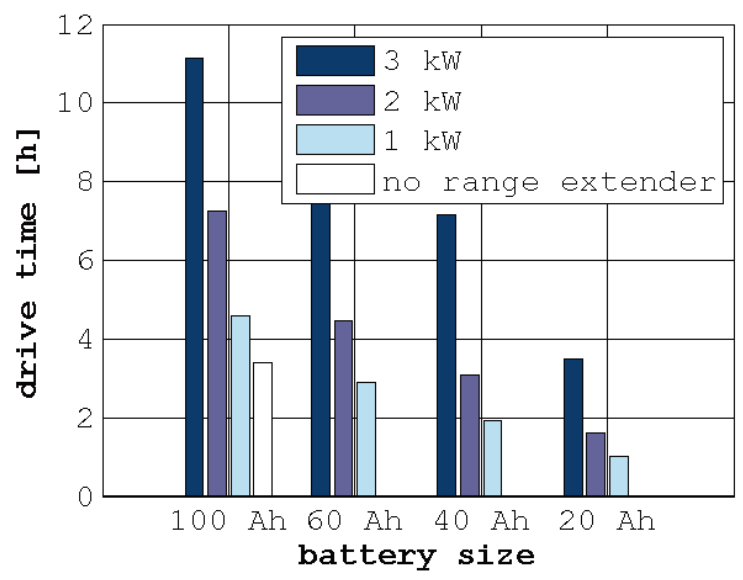

Figure 14: Parameter variation: drive-time 3.3.1 Case study 1

In many cases beside the range further boundary conditions of a specific application can influence the concept evaluation and ranking. E.g. standstill periods which allow partially battery charging, required total range or minimal driving time are essential to determine the most appropriate or cost-efficient solution. As an example two case studies with different driving profiles are given. Case study 1 focuses on an urban application like a delivery or taxi service. For this case study a minimal driving range per day of $150 \mathrm{~km}$ is assumed which is the result of 2 driving periods of $4 \mathrm{~h}$ interrupted by a break of $2 \mathrm{~h}$ (table 6). Based on these assumptions the different vehicle scenarios have been evaluated.

Those battery-SOFC combinations were selected

\begin{tabular}{|l|c|c|c|}
\hline & $\begin{array}{c}\text { Battery } \\
\text { size }[\mathrm{Ah}]\end{array}$ & $\begin{array}{c}\text { SOFC } \\
\text { size [kW] }\end{array}$ & $\begin{array}{l}\text { Ratio extended range } \\
\text { to pure battery range }\end{array}$ \\
\hline Concept 1 & 100 & 3 & 3,3 \\
\hline Concept 2 & 60 & 3 & 3,1 \\
\hline Concept 3 & 100 & 2 & 2,1 \\
\hline Concept 4 & 40 & 3 & 2,1 \\
\hline
\end{tabular}

Table 6: Specifications of case study 1

(C)

2008 WEV Journal, pp. $x-x$

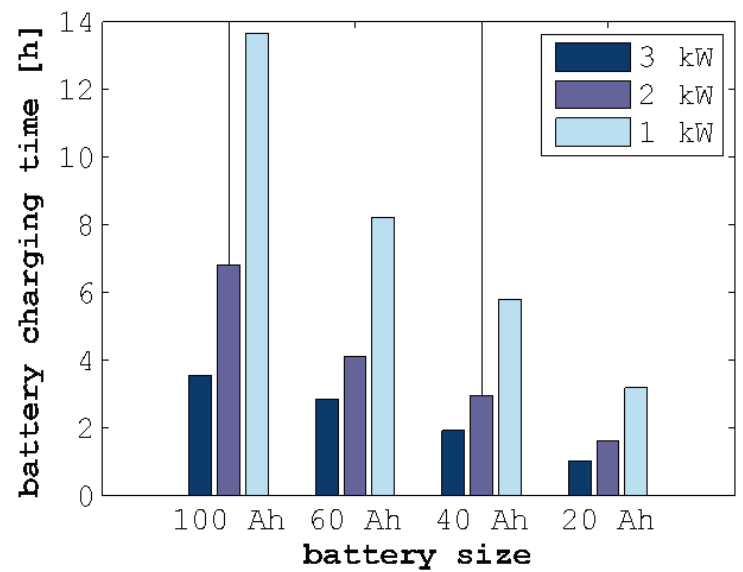

Figure 15: Parameter variation: battery charging time

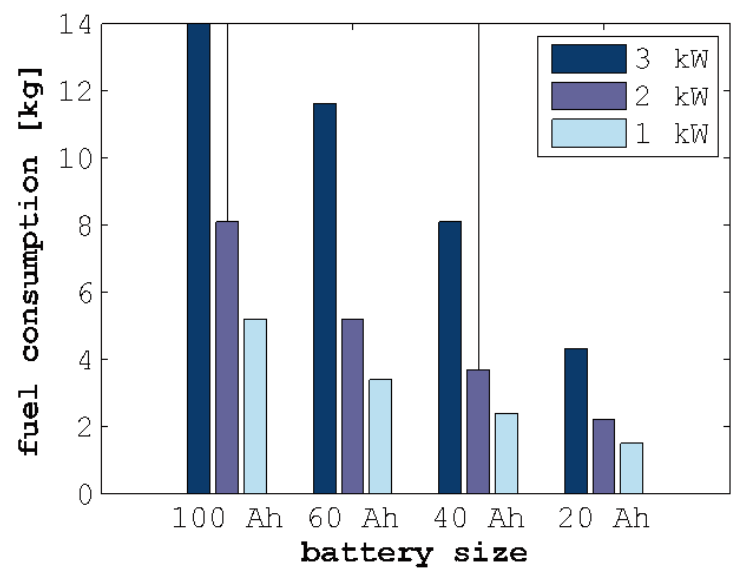

Figure 16: Parameter variation: fuel consumption allowing a driving time of at least 4 hours. The 2 hours recharging time increases the further driving time accordingly and have to allow further 4 hours continuous driving time. The concepts allowing such driving cycles are summarized with their total driving range and time in table 7 . Any other combination has to be excluded because the driving time is less than 4 hours or no appropriate recharging is possible within 2 hours. For those combinations using the $3 \mathrm{~kW}$ SOFC it has to be stated that the battery is fully recharged in less than the 2 hours standstill period. Therefore the concepts CS1-1, CS1-2 and CS1-3 are oversized for the

\begin{tabular}{|l|c|c|c|c|}
\hline & $\begin{array}{c}\text { Battery } \\
\text { size } \\
{[\mathrm{Ah}]}\end{array}$ & $\begin{array}{c}\text { SOFC } \\
\text { size } \\
{[\mathrm{kW}]}\end{array}$ & $\begin{array}{c}\text { Total } \\
\text { driving } \\
\text { time [h] }\end{array}$ & $\begin{array}{c}\text { Total } \\
\text { range } \\
{[\mathrm{km}]}\end{array}$ \\
\hline $\begin{array}{l}\text { Concept } \\
\text { CS1-1 }\end{array}$ & 100 & 3 & 15 & 314 \\
\hline $\begin{array}{l}\text { Concept } \\
\text { CS1-2 }\end{array}$ & 60 & 3 & 11,5 & 250 \\
\hline $\begin{array}{l}\text { Concept } \\
\text { CS1-3 }\end{array}$ & 40 & 3 & 11 & 235 \\
\hline $\begin{array}{l}\text { Concept } \\
\text { CS1-4 }\end{array}$ & 100 & 2 & 9 & 193 \\
\hline
\end{tabular}

Table 7: Potential battery-SOFC combinations for case study 1, ranked according to their total range 
given application.

\subsubsection{Case study 2}

On the contrary case study 2 is based on a driving profile of a breakdown service defined by half an hour driving time followed by half an hour standstill time in turns. For this evaluation the $3 \mathrm{~kW}$ SOFC is neglected because it is clearly oversized based on the results of case study 1. Evaluation of the remaining concepts results in the fact that concepts $\mathrm{CS}_{2}-1$ and $\mathrm{CS} 2-3$ are also oversized. The optimum is obtained with concept CS2-5 (40 Ah battery, $2 \mathrm{~kW}$ SOFC) and CS2-7 (20 Ah battery, $2 \mathrm{~kW}$ SOFC) because in both cases the driving time equals the charging time. A driving profile of 0,5 hours driving and 0,5 hours charging results therefore in a $100 \%$ charged vehicle. Since the range of CS2-3 is twice that of $\mathrm{CS} 2-5$ concept $\mathrm{CS} 2-3$ is the most appropriate one.

\begin{tabular}{|l|c|c|c|}
\hline & $\begin{array}{c}\text { Battery } \\
\text { size } \\
{[\mathrm{Ah}]}\end{array}$ & $\begin{array}{c}\text { SOFC } \\
\text { size } \\
{[\mathrm{kW}]}\end{array}$ & $\begin{array}{c}\text { SOC after 0,5 h } \\
\text { recharging } \\
{[\%]}\end{array}$ \\
\hline Concept CS2-1 & 100 & 2 & 100 \\
\hline Concept CS2-2 & 100 & 1 & 93 \\
\hline Concept CS2-3 & 60 & 2 & 100 \\
\hline Concept CS2-4 & 60 & 1 & 73 \\
\hline Concept CS2-5 & 40 & $\mathbf{2}$ & 100 \\
\hline Concept CS2-6 & 40 & 1 & 84 \\
\hline Concept CS2-7 & 20 & $\mathbf{2}$ & 100 \\
\hline Concept CS2-8 & 20 & 1 & 67 \\
\hline
\end{tabular}

Table 8: Evaluation of battery-SOFC combinations regarding case study 2 based on their SOC, concepts highlighted are identified as optimum

\section{DISCUSSION}

The simulation study has shown that comprehensive vehicle simulations allow sophisticated analysis and optimization of vehicle concepts. Different scenarios can be evaluated and compared easily. The validation of the electric vehicle model defines an excellent basis for development and evaluation of new vehicle concepts. Especially the simulation platform Modelica proves as a flexible and efficient tool.

Main objective of the simulation study was the analysis of different hybrid electric concepts focusing especially on the size of the battery and the SOFC. Furthermore different impact factors have been investigated, like driving time, charging periods, etc. For the vehicle under investigation the simulation results have indicated that at least a $2 \mathrm{~kW}$ SOFC has to be integrated to allow an increase of the vehicle range by about a factor of 2 . The battery size on the contrary can be decreased from originally $100 \mathrm{Ah}$ down to 60 or $40 \mathrm{Ah}$ when combined with the $3 \mathrm{~kW}$ SOFC. In both cases the obtained range is about $150 \mathrm{~km} \mathrm{-} \mathrm{a}$ duplication of the pure battery range.
For a more detailed evaluation of the concepts under different boundary conditions two different driving and recharging profiles have been applied. Allowing recharging during a 2 hours standstill period after 4 hours of driving, the total range can be increased by about a factor of 3 (100 Ah battery and $2 \mathrm{~kW}$ SOFC) up to 4,8 (100 Ah battery and $3 \mathrm{~kW}$ SOFC) of the pure battery electric vehicle. However, most of the batterySOFC combinations are oversized for the given application. On the other hand a driving profile of half an hour driving time followed by half an hour standstill respectively recharging time in turns allows to decrease the battery significantly. The optimum is achieved with the $40 \mathrm{Ah}$ battery and the $2 \mathrm{~kW}$ SOFC. Since the driving and charging are balanced the range of this concept is theoretically limited by the range of the range extender.

Based on these results it can be stated that the specific application and driving profile is essential for the effective improvement that can be achieved. Regarding all these simulation results it has to be considered that they are based on an urban driving cycle. For further verification of the simulation results with respect to realization of a hybrid electric vehicle different driving cycles have to be applied in addition. In addition for selection of the most appropriate concept beside the range, driving and charging time also the battery and fuel cell costs, their weights and dimensions have to be considered.

\section{CONCLUSIONS}

Electric propulsion is a high potential solution for energy efficient and sustainable mobility. To overcome the deficits of pure battery electric vehicles the integration of a fuel cell range extender opens new possibilities for short term market introduction and increased customer acceptance. Nevertheless, the improvements that can be achieved by the hybrid electric concept highly depend on the specific driving cycle and the boundary conditions, e.g. recharging times during standstill periods, driving time without recharging possibilities, battery and SOFC costs, etc. Based on a comprehensive vehicle simulation different potential concepts have been identified and analyzed under different application scenarios.

For validation of the simulation results a hybrid electric vehicle will be realized based on case study 2 . The original $100 \mathrm{Ah}$ NiCd battery will be replaced by a $40 \mathrm{Ah}$ battery and a $2 \mathrm{~kW}$ SOFC will be integrated in a conventional electric vehicle (e.g. Citroen Berlingo electrique). Measurement on component and system level will be performed to validate the simulation models and the determined ranges for different driving cycles. It is planned to provide this hybrid electric vehicle to a breakdown service for comprehensive tests under real conditions. 


\section{REFERENCES}

[1] M. Anderman, Challenges and Opportunities for Lithium-Ion Batteries in Automotive Applications, The 22nd International Battery, Hybrid and Fuel Cell Electric Vehicle Symposium \& Exposition, EVS-22 Yokohama, Japan, Oct. 23-28, 2006

[2] T. Q. Duong, D. Howell, J. Barnes, G. Henriksen, V. Srinivasan, Current Overview of U.S. Department of Energy Research on Energy Storage for Transportation Systems, The 22nd International Battery, Hybrid and Fuel Cell Electric Vehicle Symposium \& Exposition EVS-22 Yokohama, Japan, Oct. 23-28, 2006

[3] F.V. Conte, Battery and battery management for hybrid electric vehicles: a review, Elektrotechnik \& Informationstechnik 123/10, p 1-8, 2006

[4] A. Truckenbrodt, Fuel Cell Vehicles for Future Car Concepts, 2004-21-0081, SAE World Congress 2004

[5] T. Matsumoto, N. Watanabe, H. Sugiura, T. Ishikawa, "Development of Fuel-Cell Hybrid Vehicle", 2002-01-0096, SAE World Congress 2002

[6] P. Fritzson. Principles of Object-Oriented Modeling and Simulation with Modelica 2.1. Piscataway,

NJ: IEEE Press, 2004.

[7] J.V. Gragger, D. Simic, C. Kral, H. Giuliani, F.A. Conte, F. Pirker, A Simulation Tool for Electric Auxiliary Drives in HEVs the \{SmartElectricDrives\} Library, FISITA World Automotive Congress 2006, Yokohama, Japan, 2006

[8] H. Giuliani, Simulation of a four wheel drive hybrid electric vehicle by means of the SmartElectricDrives library, Neue elektrische Antriebskonzepte für Hybridfahrzeuge, expert verlag, 2007

[9] C. Schweiger. PowerTrain Library 1.0, Modelica Automotive Workshop, Ford Research Laboratory, Dearborn, MI, USA, November 19, 2002

[10] Automobiles Peugeot, Partner Electric Motor, Beschreibung Technischer Daten, Originalnummer:7725, Ref: 1238-D-04/98

\section{AUTHORS}

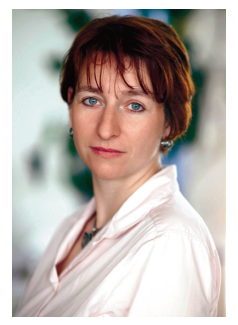

Margit Noll received her $\mathrm{PhD}$ in physics from the Vienna University of Technology in 1998 as well as an MBA in General Management from the Danube University Krems, Austria in 2001. From 1998 to 2004 she was scientific employee at the Austrian Research Centers - systems research, Austria, focusing on innovation management, technology monitoring and knowledge management. In 2004 she joined arsenal research, Vienna, Austria. Currently she is responsible for strategic research planning and research management in the field of electric drives technologies and alternative vehicle concepts at Arsenal Research.

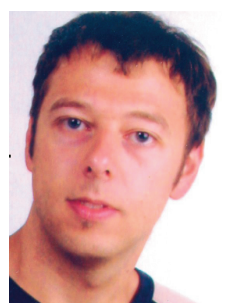

Harald Giuliani received the Dipl.-Ing. degree in electrical engineering from the Vienna University of Technology, Austria, in 2004. Since January 2005, he has been an engineer of the business unit Monitoring, Energy and Drive Technologies with arsenal research. He is mainly concerned with modeling and simulation of electric drives and machines in Modelica/Dymola.

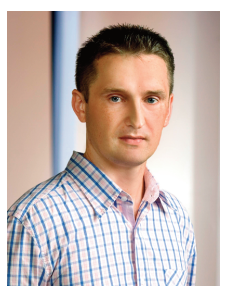

Dragan Simic received his Dipl.-Ing. degree in mechanical engineering from the Faculty of Electrical Engineering, Mechanical Engineering and Naval Architecture University of Split, Split, Croatia, in 1999. In 2007 he received his $\mathrm{PhD}$ from the Vienna University of Technology, Austria, in 2007. Since 2002, he is scientific employee at arsenal research, Vienna, Austria. His research activities are focused on the longitudinal dynamics simulation of conventional and hybrid vehicles, including the simulation of auxiliaries.

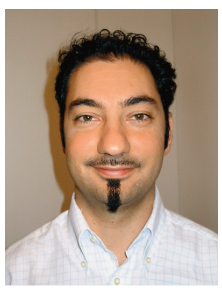

Fiorentino Valerio Conte was born 1972. He is graduated in Electrical Engineering at University of Pisa. In 2004 he received the Ph.D. degree from the University of Pisa. He is researcher of Arsenal Research's Monitoring Energy and Drives technologies business unit since 2003. His research topics are focused on testing and modeling of energy storage systems. Since 2004 he is working in the IEAHEV Annex-VII Task Force on "Hybrid \& Electric Vehicles".

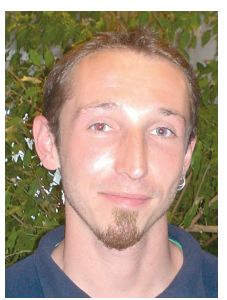

Hannes Lacher graduated in Electronic Engineering at the University of Applied Sciences Technikum Wien in 2003. In 2005 he joined arsenal research focusing especially on the development of electric components and drive trains for vehicles.

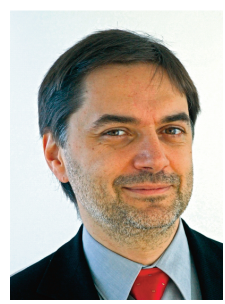

Peter Gollob attended the Graz University of Technology, Austria and received his Dipl.-Ing. degree in 1993. He worked for different companies of the Austrian automotive supplier segment, such as AVL or Magna, in the research and development departments. He joined arsenal research in 2006 as project manager for research projects covering mainly the development of new concepts of electric drives, as well as testing and environmental simulation for the automotive industry. 